\title{
Characterization of Genetic Diversity in Accessions of Prunus salicina Lindl: Keeping Fruit Flesh Color Ideotype While Adapting to Water Stressed Environments
}

\author{
Cintia V. Acuña ${ }^{1, *(\mathbb{D})}$, Juan G. Rivas ${ }^{1}$, Silvina M. Brambilla ${ }^{1}\left(\mathbb{D}\right.$, Teresa Cerrillo ${ }^{2}$, \\ Enrique A. Frusso ${ }^{3}$, Martín N. García ${ }^{1}$, Pamela V. Villalba ${ }^{1}$, Natalia C. Aguirre ${ }^{1}$, \\ Julia V. Sabio y García ${ }^{1}$, María C. Martínez ${ }^{1}{ }^{\mathbb{D}}$, Esteban H. Hopp ${ }^{1,4}$ and \\ Susana N. Marcucci Poltri ${ }^{1}$ (D) \\ 1 Instituto de Agrobiotecnología y Biología Molecular-IABiMo-INTA-CONICET, Instituto de Biotecnología, \\ Centro de Investigaciones en Ciencias Agronómicas y Veterinarias, Instituto Nacional de Tecnología \\ Agropecuaria, Dr. Nicolás Repetto y de los Reseros S/N, Hurlingham, Buenos Aires B1686IGC, Argentina \\ 2 EEA Delta del Paraná, Río Paraná y Canal Laurentino Comas, Campana (2804), \\ Buenos Aires B1686IGC, Argentina \\ 3 Instituto de Recursos Biológicos, Centro de Investigación de Recursos Naturales, Instituto Nacional de \\ Tecnología Agropecuaria, Dr. Nicolás Repetto y de los Reseros S/N, \\ Hurlingham, Buenos Aires B1686IGC, Argentina \\ 4 Lab. Agrobiotecnología, FBMC, Facultad de Ciencias Exactas y Naturales, Universidad de Buenos Aires, \\ Intendente Güiraldes 2160, Ciudad Universitaria, CABA C1428EGA, Argentina \\ * Correspondence: acuna.cintia@inta.gob.ar; Tel.: +54-11-4621-1278; Fax: +54-11-4621-0199
}

Received: 14 June 2019; Accepted: 17 August 2019; Published: 27 August 2019

\begin{abstract}
The genetic diversity of 14 Japanese plum (Prunus salicina Lindl) landraces adapted to an ecosystem of alternating flooding and dry conditions was characterized using neutral simple sequence repeat (SSR) markers. Twelve SSRs located in six chromosomes of the Prunus persica reference genome resulted to be polymorphic, thus allowing identification of all the evaluated landraces. Differentiation between individuals was moderate to high (average shared allele distance $(\mathrm{DAS})=0.64$ ), whereas the genetic diversity was high (average indices polymorphism information content $(\mathrm{PIC})=0.62$, observed heterozygosity $(\mathrm{Ho})=0.51$, unbiased expected heterozygosity $(\mathrm{uHe})=0.70$ ). Clustering and genetic structure approaches grouped all individuals into two major groups that correlated with flesh color. This finding suggests that the intuitive breeding practices of growers tended to select plum trees according to specific phenotypic traits. These neutral markers were adequate for population genetic studies and cultivar identification. Furthermore, we assessed the SSR flanking genome regions $(25 \mathrm{~kb})$ in silico to search for candidate genes related to stress resistance or associated with other agronomic traits of interest. Interestingly, at least 26 of the 118 detected genes seem to be related to fruit quality, plant development, and stress resistance. This study suggests that the molecular characterization of specific landraces of Japanese plum that have been adapted to extreme agroecosystems is a useful approach to localize candidate genes which are potentially interesting for breeding.
\end{abstract}

Keywords: Japanese plum; SSR; diversity; genetic structure; candidate genes

\section{Introduction}

The genus Prunus consists of more than 400 species, of which plum, peach, almond, and cherry trees stand out for their commercial importance worldwide. The Japanese plum (Prunus salicina Lindl) is one of the most commercially important plum species. This diploid $(2 x=2 n=16)$ species has been 
cultivated in different environments and was introduced to North America from China in the 19th century [1]. Today, most Japanese plum cultivars grown worldwide come from the early selections originated in California at the end of the 19th century [2]. Besides, most planted plum orchards in other extensive production regions of Argentina derive from a few introduced cultivars of global distribution.

By contrast, European immigrant growers early in the last century who settled in the Paraná River Delta (PRD) introduced old traditional cultivars from their European countries. They selected wild plants emerged by the spontaneous sowing of seeds of the introduced varieties that they cultivated based on good performance and high-quality traits. Growers from the PRD had to face a particularly harsh environmental ecosystem.

The PRD is a unique ecosystem dominated by floods because of water discharges mainly from the Paraná River followed by discharges from the Uruguay and Gualeguay rivers. Tidal and storm surges from the Río de la Plata estuary as well as local rainfalls also contribute to generate these wetlands [3]. Precipitations in this region are influenced by the El Niño Southern Oscillation (ENSO) [4]. Indeed, three important floods associated with El Niño took place in PRD in 1982, 1998, and 2007 [3,5]. Furthermore, the alternation of wet and dry periods in the PRD influences the variability of the ecosystem. All these features give place to at least 15 landscape units [3] with a high ecological diversity distinctly adapted to annual hydrological cycles [6].

In this climate context, growers from the PRD generated local plum landraces that were cultivated after multiplication by grafting or from seeds, and therefore obtained the best wetland-adapted plants. In this way, they intuitively created a specific fruit tree germplasm for fruit production in an ecosystem with harsh environmental conditions that alternates river flooding periods with extreme dry season. The generated germplasm, which presents different harvest times (November to February, Table 1), is highly variable regarding pulp and skin coloration, as well as in its organoleptic characteristics.

Table 1. Characteristics of the landraces collected from the Paraná River Delta (PRD).

\begin{tabular}{|c|c|c|c|}
\hline Landrace & Origin & Flesh Color & Harvest \\
\hline Ratto & Seedling Delta & red & Very late season-End of January \\
\hline Severiana & Seedling Delta & red & $\begin{array}{c}\text { Very late season-End of January to } \\
\text { mid-February }\end{array}$ \\
\hline Remolacha de Berisso & Seedling Delta & red & $\begin{array}{c}\text { Very late season-End of January to } \\
\text { early February }\end{array}$ \\
\hline Fragata & Seedling Delta & red & Very late season-End of January \\
\hline Remolacha de Leber & Seedling Delta & red & $\begin{array}{c}\text { Middle season-Early/middle } \\
\text { December }\end{array}$ \\
\hline Gigaglia & Seedling Delta & red & $\begin{array}{c}\text { Middle season-Mid-November to } \\
\text { early December }\end{array}$ \\
\hline Capri & Seedling Delta & red & Late season-Late December \\
\hline Giordano & Seedling Delta & red & $\begin{array}{c}\text { Middle season-Late November to } \\
\text { early December }\end{array}$ \\
\hline Ciervita & Seedling Delta & pink & Early season-Mid-to late November \\
\hline Reina de oro & Seedling Delta & yellow & Late season-Early January \\
\hline Juanita & Seedling Delta & yellow & $\begin{array}{l}\text { Early season-Mid-November to } \\
\text { early December }\end{array}$ \\
\hline Gascón & Seedling Delta & yellow & $\begin{array}{c}\text { Middle season-Late November to } \\
\text { early December }\end{array}$ \\
\hline Tricerri & Seedling Delta & yellow & Mid-November \\
\hline “ $X^{\prime \prime}$ & Seedling Delta & yellow & Mid-November \\
\hline
\end{tabular}

Thus, Japanese plum landraces selected in the PRD are a unique genetic resource in the world, and one of the few adapted to delta edaphic conditions and to humid temperate climate [7]. These landraces could constitute the closest reservoirs of "useful" alleles for future genetic improvement in the context of climate change. They contain the genetic variants naturally or artificially selected by growers because of their adaptation, productivity, or resistance to different stresses in the territory $[4,5]$. The knowledge of this interesting germplasm collection's diversity is essential for its characterization, conservation, and maintenance, as proposed for sweet cherry [8]. 
Genomics has triggered a revolution in the study of diversity $[9,10]$ and conservation [11] by providing methods for the genetic characterization of individuals, populations, and species. The availability of Prunus genomic resources such as peach whole-genome sequences [12] allows the search for sequences of interest for breeding purposes (see for review [13]).

Mnejja et al. [2] isolated 27 microsatellites or simple sequence repeats (SSRs) in P. salicina, whereas Carrasco et al. [14] analyzed genetic diversity and correlation among 29 Japanese plum cultivars using a combination of inter simple sequence repeat (ISSR) and SSR markers. On the other hand, Klabunde et al. [15] genotyped 47 cultivars with eight microsatellite markers. A unique genetic map based on Restriction Fragment Length Polymorphism (AFLP) has been generated for this species [16]. Recently, González et al. [17] reported a set of EST-SSR markers for P. salicina developed from specific genes, which determine different organoleptic properties of the fruit, and analyzed 29 cultivars with these markers.

Microsatellite markers generate genotype profiles that can allow the identification and traceability of different cultivars in the diverse stages of their breeding. Therefore, the use of microsatellite markers could be a valuable tool to describe and protect Japanese plum germplasm. In addition, the genome position of SSR on a reference genome, together with potential candidate genes for fruit properties and self-incompatibility systems, could also be a useful tool for breeding purposes [13].

This unique plum germplasm was studied through the use of SSR markers to assess the diversity, genetic structure, and relationships between 14 landraces of Japanese plums from the PRD. Therefore, we also analyzed the flanking regions of the polymorphic SSR with bioinformatics tools to search for candidate genes. These candidate genes were in linkage disequilibrium with polymorphic SSR markers in an adaptive evolution to water stress conditions and fruit quality.

\section{Materials and Methods}

\subsection{Plant Material}

Fourteen landraces of $P$. salicina and two introduced commercial cultivars were assessed to evaluate amplification and polymorphic status of the 12 selected pairs of primers from Mnejja et al. [2]. The analyzed landraces were "Ratto", "Severiana", "Remolacha de Berisso", "Fragata", "Remolacha de Leber", "Gigaglia", “Capri", "Ciervita", "Giordano", "Reina de oro", “Juanita", "Tricerri", "X" (unknown origin), "Gascón". The introduced cultivars consisted of one Japanese plum of American origin ("Santa Rosa") and one European plum cultivar (P. domestica; "Reina Claudia"). Two peach cultivars (P. persica) "Sol de Mayo" and "Zelanda" were included as outgroups (Table 1). All samples were collected from one representative tree of each clonally reproduced genotype located in the Pacífico River, San Fernando Island of the PRD, Province of Buenos Aires, Argentina ( $34^{\circ} 12^{\prime} 01.62^{\prime \prime}$ S, $\left.58^{\circ} 40^{\prime} 07.66^{\prime \prime} \mathrm{W}\right)$.

\subsection{DNA Extraction, $P C R$, and Gel Electrophoresis Conditions}

Total genomic DNA from $20 \mathrm{mg}$ of leaf samples was extracted with a Nucleo SpinR Plant II kit (Macherey-Nagel, Düren, Germany).

The samples were screened for polymorphisms with 12 SSR markers [2]. PCR was performed according to Mnejja et al. [2]. The amplification products were denatured for $5 \mathrm{~min}$ in denaturing loading buffer at $95{ }^{\circ} \mathrm{C}$ and separated by a $6 \%$ polyacrylamide gel electrophoresis $(6 \%$ acrylamide/bisacrylamide 20:1, 7.5 M urea, 0.5 × TBE) along with a 25 bp DNA ladder standard (Invitrogen, Waltham, USA). The DNA silver-staining procedure of Promega (Madison, WI, USA) was used for visualization.

\subsection{Genetic Analyses}

The number $(\mathrm{Na})$, effective number $(\mathrm{Ne})$ and frequency of alleles, as well as the observed heterozygosity (Ho), unbiased expected heterozygosity (uHe), and private alleles by population 
were determined for the 14 local Japanese plums samples using the GenAlEx 6.5 program [18]. The polymorphism information content (PIC) of each marker was calculated according to Botstein et al. [19].

Genetic diversity analysis was performed on plum and peach genotypes. Shared allele distance (DAS) [20] was implemented between individuals using POPULATIONS 1.2.28 [21]. The unweighted pair group method using arithmetic averages (UPGMA) algorithm was used for cluster analysis and the development of the corresponding dendrogram2.4. Population Structure.

The population structure pattern was assessed by performing a Bayesian analysis with the software STRUCTURE v.2.3.3 [22]. Assignment of individuals to a group was evaluated according to the membership coefficient $Q$ criteria $(Q \geq 0.8)$. The model used was an admixture model with ten replicates for each number of genetic groups $(K=1-10)$ and 100,000 iterations of burn-in followed by 250,000 Markov chain Monte Carlo (MCMC) iterations. The outputs of the genetic group analysis were extracted in Structure Harvester [23]. The optimal K-value was determined using the delta K method, as described by Evanno et al. [24].

Because the assumptions underlying the population genetic model in STRUCTURE (e.g., Hardy-Weinberg or linkage equilibrium (LD)) may limit its use, this analysis was complemented with a discriminant analysis of principal components (DAPC) [25]. The value of $\mathrm{K}$ was determined using the Bayesian Information criterion (BIC) value given by the software [26]. The critical membership value was set at 0.8 . The DAPC was implemented in the R package adegenet $2.0[27,28]$.

\subsection{Mapping of SSR Markers on the Prunus persica Genome and Identification of Their Flanking Genes}

The obtained amplification sequences for the 12 SSR were mapped to the P. persica genome [29] (Phytozome-Prunus persica v2.1 (phytozome.jgi.doe.gov)). Mapping was performed using the Bowtie2 Alignment tool with default settings [30]. A custom Perl script (Higgins J., personal communication) was used to determine the annotated genes of the P. persica genome within a flanking region of $50 \mathrm{~kb}$ ( $\pm 25 \mathrm{~kb}$ adjacent to each SSR locus). This window size was selected based on the high macrosynteny found between Prunus species [31] and studies in sweet cherry (P. avium L), which presents the lowest LD in Prunus genus. Indeed, in sweet cherry, the intra-chromosomal LD is lower than peach, therefore declining among 0.05 and $0.1 \mathrm{Mb}[8]$.

\section{Results}

\subsection{Diversity Study}

All SSRs generated polymorphic bands in the 14 P. salicina landraces (Table 2). The alleles were clearly differentiated, with no discrepancies in the banding pattern.

The 12 polymorphic SSRs in the 14 evaluated local landraces of Japanese plums generated 66 different alleles (Electronic Supplementary Material, Table S1). The Na per locus ranged from four to seven, with a mean of 5.5 (SD 1.0), and the Ne ranged from 2.2 to 4.2 , with a mean of 3.1 (SD 0.6). Additionally, PIC, Ho, and uHe ranged from 0.51 to $0.73,0.15$ to 0.86 , and 0.56 to 0.79 , with global means of 0.62 (SD 0.06), 0.51 (SD 0.23), and 0.70 (SD 0.06), respectively (Table 2). Thus, the genetic diversity levels were moderate to high, and kept 37 private alleles in 12 SSRs ( 20 with a frequency below 0.08 ) with respect to 4 private alleles in 4 SSRs (all of them with a frequency of 0.25 ) found in the analyzed outgroups.

\subsection{Cluster and Genetic Structure Analyses}

These 12 SSRs allowed the unambiguous genotype differentiation of the 14 landraces studied. DAS values between plum individuals fluctuated from 0.14 (between "Ratto" and "Severiana", which shared 19 alleles out of 24) to 1 (between "Reina de oro" and "Remolacha de Berisso"; with no shared alleles), with an average DAS of 0.64 among all the landraces (Electronic Supplementary Material, Table S2). 
In order to easily represent the genetic relationship among all samples, a DAS-based dendrogram was developed. Therefore, the genotypes were grouped in three main groups (Figure 1). One group contained nine accessions with red flesh fruits (Group 1: "Ratto", "Severiana", "Remolacha de Berisso", "Fragata", "Remolacha de Leber", "Gigaglia", "Capri", "Ciervita", and "Giordano") and within this group "Ratto" and "Severiana" were the closest genotypes (DAS = 0.14). A second group consisted of seven accessions with yellow flesh fruits (Group 2: "Reina de oro", "Juanita”, “Tricerri", "X”, "Gascón”, and the two introduced commercial genotypes "Santa Rosa" and "Reina Claudia"). The sample from the " $X$ " landrace showed higher genetic similarity with "Tricerri" (DAS $=0.31$ ) but differed from all the other samples. Finally, the third group contained the outgroup varieties, that is, the two peach samples (Group 3: "Sol de Mayo" and "Zelanda").

Table 2. Information of the 12 analyzed polymorphic simple sequence repeat (SSR) markers in 14 local landraces of Japanese plums.

\begin{tabular}{|c|c|c|c|c|c|c|c|c|}
\hline SSR Marker & Location & $\mathrm{AR}(\mathrm{pb})$ & $\mathbf{N}$ & $\mathrm{Na}$ & $\mathrm{Ne}$ & Ho & uHe & PIC \\
\hline $\begin{array}{c}\text { CPSCT011 } \\
\text { (AY426199.1) }\end{array}$ & C 5 (4163117-4164052) & $171-189$ & 13 & 6 & 3.04 & 0.38 & 0.70 & 0.63 \\
\hline $\begin{array}{c}\text { CPSCT018 } \\
\text { (AY426204.1) }\end{array}$ & C 8 (123199-124139) 3e- & $151-172$ & 13 & 6 & 2.18 & 0.23 & 0.56 & 0.51 \\
\hline $\begin{array}{c}\text { CPSCT021 } \\
(\text { AY426206.1) }\end{array}$ & C 2 (27308766-27309699) & $132-157$ & 11 & 6 & 3.66 & 0.36 & 0.76 & 0.69 \\
\hline $\begin{array}{l}\text { CPSCT022 } \\
\text { (AY426207.1) }\end{array}$ & C 5 (16620819-16621314) & 159-179 & 13 & 7 & 2.91 & 0.77 & 0.68 & 0.62 \\
\hline $\begin{array}{l}\text { CPSCT024 } \\
\text { (AY426209.1) }\end{array}$ & C 1 (28058204-28058903) & $157-179$ & 13 & 4 & 2.89 & 0.61 & 0.68 & 0.60 \\
\hline $\begin{array}{l}\text { CPSCT025 } \\
\text { (AY426210.1) }\end{array}$ & C $3(6709070-6709740)$ & $181-223$ & 12 & 5 & 2.51 & 0.66 & 0.64 & 0.53 \\
\hline $\begin{array}{c}\text { CPSCT026 } \\
\text { (AY426211.1) }\end{array}$ & C 7 (11365276-11365753) & $176-195$ & 14 & 4 & 2.78 & 0.43 & 0.66 & 0.60 \\
\hline $\begin{array}{l}\text { CPSCT027 } \\
\text { (AY426212.1) }\end{array}$ & C 1 (23010058-23010528) & $137-156$ & 13 & 5 & 2.66 & 0.31 & 0.65 & 0.57 \\
\hline $\begin{array}{c}\text { CPSCT030 } \\
\text { (AY426215.1) }\end{array}$ & C 5 (15121388-15122031) & $179-200$ & 14 & 7 & 4.21 & 0.86 & 0.79 & 0.73 \\
\hline $\begin{array}{c}\text { CPSCT034 } \\
\text { (AY426219.1) }\end{array}$ & C 2 (29946149-29946699) & $177-224$ & 14 & 6 & 3.70 & 0.64 & 0.76 & 0.68 \\
\hline $\begin{array}{c}\text { CPSCT042 } \\
\text { (AY426226.1) }\end{array}$ & C 7 (16682143-16682742) & $167-185$ & 14 & 5 & 3.53 & 0.71 & 0.74 & 0.67 \\
\hline $\begin{array}{c}\text { CPSCT044 } \\
\text { (AY426228.1) }\end{array}$ & C 2 (20793617-20794126) & $218-241$ & 13 & 5 & 3.35 & 0.15 & 0.73 & 0.65 \\
\hline Mean & & & & 5.50 & 3.12 & 0.51 & 0.70 & 0.62 \\
\hline SD & & & & 1.00 & 0.58 & 0.23 & 0.06 & 0.06 \\
\hline
\end{tabular}

Location on the reference genome of $P$. persica, C: chromosome, AR: allele size ranges (pb), N: sample size, Na: number of alleles, Ne: effective number of alleles, Ho: observed heterozygosity, uHe: unbiased expected heterozygosity, PIC: polymorphism information content, SD: standard deviation.

Subsequently, the Bayesian analysis [22] supported the existence of a genetic structure among the studied genotypes, with a most probable value of $K=3$ subpopulations. All the accessions except for "Ciervita" $(Q=0.77)$ were assigned to a group with $Q$ values above 0.85 . The low membership value (Figure 2a) for "Ciervita" suggests a possible genetic mixed origin of this variety.

Similarly, the DAPC analysis also retrieved $K=3$ genetic groups according to cultivar flesh color (Figure $2 b$ ). This analysis supported the results obtained by the Bayesian model and the genetic distance results.

These three main groups had several private alleles, and half of these alleles were at a very low frequency in plums. For instance, the red pulp group (9 genotypes) presented 13 private alleles (9 SSRs) and 5 alleles with a frequency below 0.06 . The yellow pulp group ( 7 genotypes) contained 26 private alleles (11 SSRs), of which 10 had a frequency below 0.08 . Both peaches had 10 private alleles (8 SSRs), and all these alleles showed a frequency above 0.25 .

Comparison of the genotypic and phenotypic data enabled the identification of a marker/allele related to flesh color phenotype. Marker CPSCT25 revealed an allele of $193 \mathrm{bp}$ that was exclusively present in all the red flesh plums. Allele "193-bp" was present in a heterozygous or homozygous 
state (Electronic Supplementary Material, Table S1). BLASTx search using the sequences harboring CPSCT25 against the GenBank non-redundant protein database revealed significant matches with P. persica protein FAR1-Related sequence 6.

Another SSR marker, CPSCT11, presented a private allele, allele "171-bp". This allele was present in all the yellow flesh plums, except for the "Reina de Oro" cultivar, but absent from the red flesh plums (Electronic Supplementary Material, Table S1). BLASTx search using the sequences harboring CPSCT11 revealed significant matches with P. mume abscisic acid receptor PYR1 isoform X1. Both FAR1 and PYR1 are related to the abscisic-acid-mediated signaling pathway and to seed germination regulation [32].

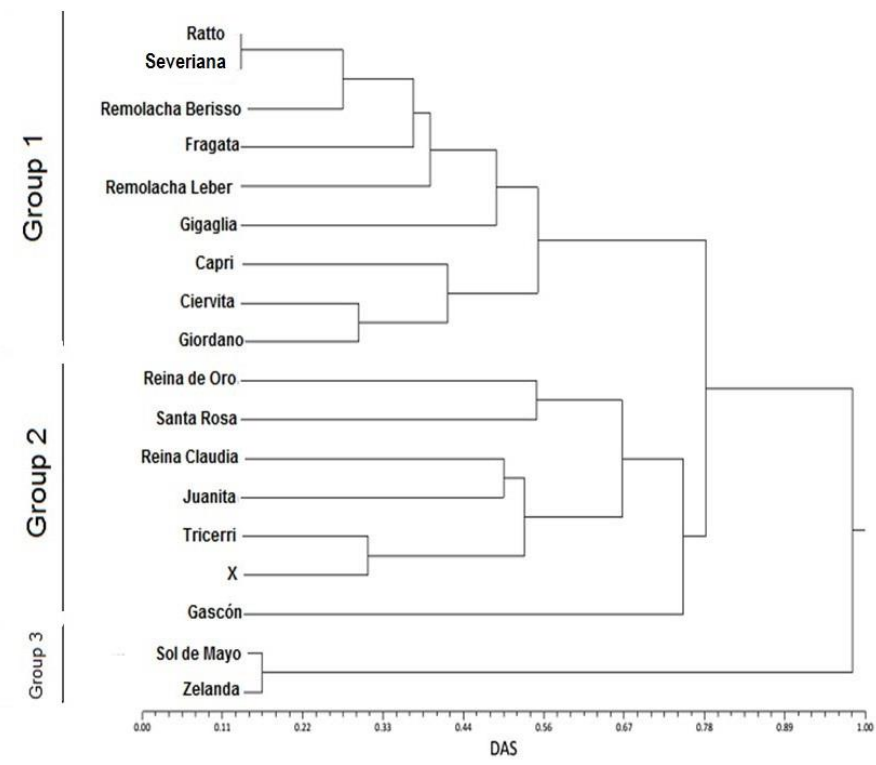

Figure 1. Cluster analysis. Dendrogram obtained by unweighted pair group method using arithmetic averages (UPGMA) calculated by shared allele distance (DAS) based on 12 SSRs. Group 1: red flesh plums, Group 2: yellow flesh plums, Group 3: outgroups (peach samples).

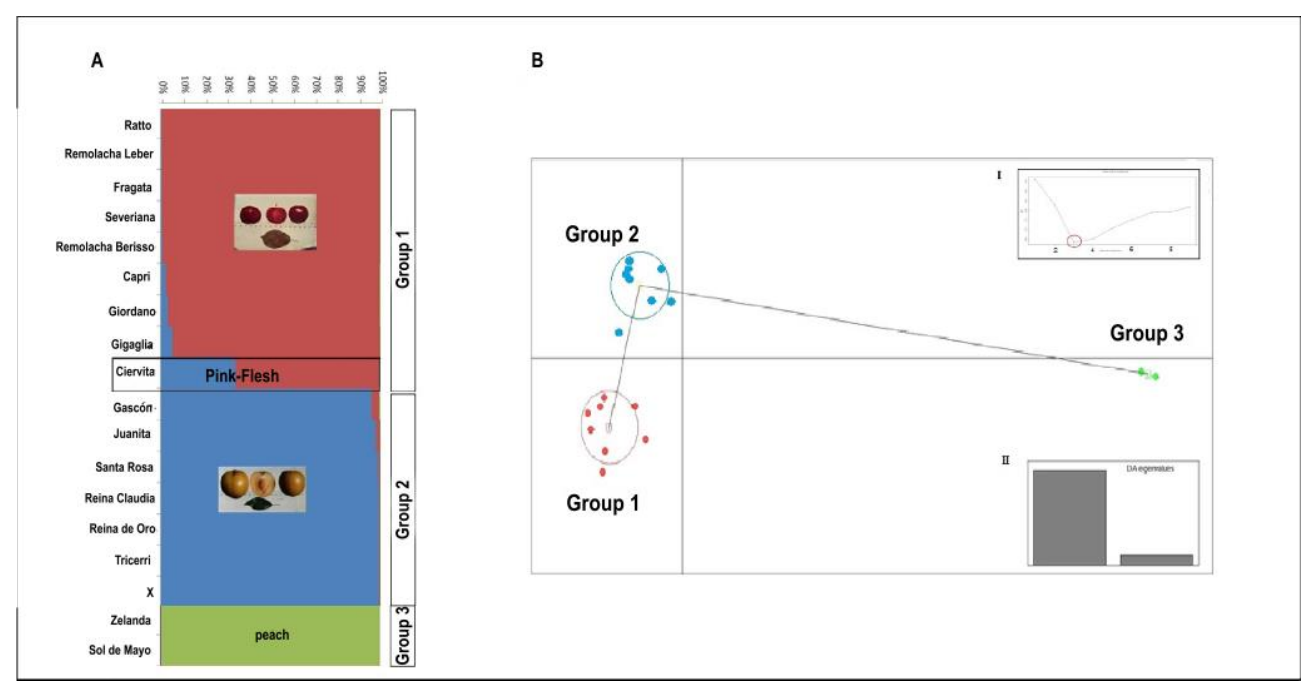

Figure 2. Estimated population structure. Genetic structure of 16 plum genotypes (14 landraces and two introduced cultivars) analyzed as estimated by (A) model-based Bayesian cluster analysis implemented in the program Structure; and (B) discriminant analysis of principal components (DAPC) implemented in the adegenet package of R software. Inset I: Inference of the number of clusters (Clusters vs. Bayesian information criterion (BIC)). Inset II: Relative importance of the two most important axes. 


\subsection{Mapping of SSR Markers on the Prunus persica Genome and Identification of Their Flanking Genes}

The sequences containing polymorphic SSR were mapped and annotated on the reference genome of $P$. persica. The loci were physically mapped to a unique position on six out of eight chromosomes $(1,2,3,5,7$, and 8$)$ (Table 2) with sequence similarities above $85 \%$.

By an in-silico analysis, we identified 118 genes located within the $50 \mathrm{~kb}$ windows flanking the SSRs.

Interestingly, within these genes, some candidates were related to stress resistance (NAC transcription factor and glutathione S-transferases (GSTs)), fruit quality (Squamosa, AGAMOUS-like MADS box, Transducin/WD40 repeat-like superfamily protein and possibly NAC), plant growth and development (VQ motif-containing proteins and microspore-specific promoter proteins) (Electronic Supplementary Material, Table S3).

\section{Discussion}

In this study, we detected high levels of diversity within 14 different plum landraces from the PRD region that have been selected through the years by local growers. The diversity indexes were lower than those described by Carrasco et al. [14] $(\mathrm{He}=0.80$ and $\mathrm{Ho}=0.90)$ and Ferrero Klabunde et al. [15] (PIC $=0.80$ and Ho $=0.77$ ) with eight SSR markers. However, this was expected due to a higher number of $P$. salicina cultivars analyzed ( 29 and 47 , respectively). On the other hand, the PIC value detected in the present study was closer to the value obtained in a study of 24 cultivars from different areas in China evaluated with 16 SSR markers (PIC $=0.7$ ) [33]. Likewise, the levels of diversity in our study were similar to or higher than those of other Prunus species, such as peach $(\mathrm{Ho}=0.35$; $\mathrm{He}=0.55[34])$, apricot $(\mathrm{Na}=3.5 ; \mathrm{Ho}=0.58$ [35]), and cherry $(\mathrm{He}=0.66 ;[36])$.

Although the number of genotypes analyzed in this study was small, the degree of diversity was high. This could be due to the mating system of P. salicina. Indeed, $P$. salicina requires cross-pollination because of its strong gametophytic self-incompatibility system, and this characteristic makes it more diverse [37] and heterozygous. Cross-pollination may have played an important role in the evolution of landraces in the PRD region because early 20th century producers very likely multiplied their trees by seed planting instead of vegetative cloning.

The 12 SSRs allowed the unambiguous identification of the genotypes studied (DAS values between plum individuals $\geq 0.14$ ). Thus, the 14 evaluated plum landraces were genetically unique (i.e., with SSR genotypes different from the rest). Cases of synonyms among samples with different names but identical SSR profiles at the 12 analyzed loci were discarded.

The cluster analysis (UPGMA) grouped the plum genotypes into two groups: plums with red and yellow flesh, respectively. Half of the private alleles of both groups occurred in a low frequency. Furthermore, the genetic relationship analysis supported the existence of genetic structure within the studied landraces. The two different methods of accessing genetic structure (Bayesian and DAPC analyses) coincided in differentiating the landraces based on the color of fruit flesh. The high $Q$ values in the Bayesian study could reflect the selection history in response to flesh color.

Particularly, the membership of "Ciervita" to a group varied depending on the software applied. This characteristic suggests a genetic mixed origin in this landrace. Interestingly, "Ciervita" has fruits with a pink flesh phenotype.

Another interesting result is that "Santa Rosa" and "Reina Claudia" were grouped within Group 2, that is, based on a phenotypic characteristic of fruits (yellow flesh fruits). Because both are introduced commercial cultivars and have some private alleles, we would have expected that these cultivars were within another group, or at least that they would differ more from the rest of the genotypes within this group. With the use of more (or different) SSRs, we may obtain different results, and these independent cultivars would be separated from these groups.

By contrast, González et al. [17] found that the cultivars they evaluated in their study were grouped based on other characteristics. They used SNPs and EST-SSR markers developed from the putative flavonoid pathway transcription factors to study the genetic structure. Only when using 
the specific markers EST-SSR (PsMYB10, PsMYB1, and PsbHLH35) did they obtain three clusters of cultivars related to the skin color: two cultivars with red skin fruits and a third cluster that grouped all the cultivars with yellow skin fruits.

Although nutritional traits like the anthocyanin content of plum fruit flesh are interesting, the reason for characterizing PRD landraces was because of their unique adaptation to a peculiar water-stressed ecosystem. Many genes may contribute to this adaptation, and for this reason the first goal was to represent-as much as possible-a plum genome with this rather limited number of molecular markers. The genetic mapping of SSR loci to the P. persica v2.1 genome enabled us to establish the position of the 12 polymorphic SSR markers used. The next step was to evaluate if these polymorphic markers were flanked, probably linked, to genes that could be associated to water stress conditions. The information of annotated genes nearby polymorphic SSRs $(<25 \mathrm{~kb})$ allowed us to describe the context of the markers and provided a first step to future association studies by identifying candidate genes for the expression of important agronomical characteristics.

We identified 118 genes located within the 50-kb windows. Of these genes, 106 corresponded to homologous genes described in Arabidopsis. Anatomical and physiological comparisons between Arabidopsis and Prunus species indicated marked similarities between them [35]. Cautiously taking into account the phylogenetic distance between Prunus and Arabidopsis, as well as their enormous biologic differences, we found some similarities in predicted gene functions that were also found in various plant taxonomic groups. Therefore, we detected candidate genes related to stress resistance, fruit quality, and other interesting candidate genes (Electronic Supplementary Material, Table S3).

For instance, genes encoding Acyl-CoA N-acyltransferases (NAT) superfamily proteins found close to marker CPSCT021 are associated with flavor generation during ripening in some fruit species, such as apricot [38] and peach [39]. Marker CPSCT022 was also close to other genes associated with fruit ripening and quality: SQUAMOSA MADS Box [40] and AGAMOUS-like MADS box genes [41,42]. Interestingly, these two genes have been also associated with the metabolic pathway of anthocyanins responsible for fruit color. Indeed, they were associated with the regulation of anthocyanin accumulation or synthesis in pear and Arabidopsis [43,44], as well as in bilberry [45]. Anthocyanin biosynthesis is cooperatively regulated by transcriptional regulators, including WD40 proteins (adjacent to CPSCT042). These regulators form a complex that binds to promoters and activates the transcription of structural genes of the anthocyanin biosynthetic pathway [46]. In addition, an alpha/beta-hydrolases superfamily protein involved in delaying fruit senescence under low temperature in strawberry fruit [47] was close to marker CPSCT025 (Electronic Supplementary Material, Table S3).

Stress-related genes corresponding to the NAC (No Apical Meristem) domain transcriptional regulator superfamily protein and tau-type glutathione S-transferases (GSTs) $[48,49]$ were located close to CPSCT024. Additionally, stress-related genes encoding reversibly glycosylated polypeptide (RGP family) [50] and the bZIP transcriptional regulator gene [51] were adjacent to CPSCT022 and CPSCT042, respectively.

The NAC protein consists of a large and complex family of transcription factors that are involved in multiple biological processes in plants, including perception of biotic/abiotic stress, signal transduction, transcription control, and gene activation. The NAC transcription factors regulate the differentiation of cells specialized for water conduction in vascular plants, and their conserved genetic basis suggests roles for NAC proteins in the adaptation of plants to land [52].

Interestingly, NAC (close to CPSCT024) was also related to cold-stress responses in P. mume [53], and to the metabolic pathway of anthocyanins responsible for fruit color in different plants such as peach, plum, and Arabidopsis [54-56].

On the other hand, the bZIP families described by Janiak et al. [51] have a role in gene expression regulation in roots and may have an impact on root development under drought stress conditions.

Furthermore, genes involved in plant growth and development encoding VQ motif-containing proteins and microspore-specific promoter proteins $[57,58]$ were close to CPSCT011. 
Although the evaluated sample size was too small to define associated markers by association mapping analysis through haploblocking definition (genetic blocks where alleles are grouped in linkage disequilibrium without recombination), pedigree history could also explain this result [13].

Further analyses are needed to assess the potential contribution of these genes to the specific adaptation of the local landraces to water-stressed environments. Some, or even all, of the allele associations described above, could still be attributed to demographic or management reasons that have nothing to do with adaptation to the environment.

In peach, an analysis of 53 SSRs distributed through the genome was carried out in 104 landraces from six Chinese geographical regions, determining an LD decay across all populations of $2500 \mathrm{~kb}$ [59]. However, lower LD decay was found in grape $(\sim 1300 \mathrm{~kb})$ [60] and in sweet cherry $(\sim 100 \mathrm{~kb})[8]$, independently of the number and type of molecular markers used. In our work, the evaluated sequences for searching interesting candidate genes were up to $25 \mathrm{~kb}$ distance from the SSR markers, so we expect that linkage between them is high enough to be considered in future breeding studies with association markers.

The findings described here could provide an interesting working hypothesis for future research in plum molecular breeding. The incorporation of the markers linked to the annotated genes in this study could be of high value in marker-assisted selection breeding programs and in future genome-wide association studies (GWAS).

\section{Conclusions}

This is the first study characterizing a representative sample of different plum landraces adapted to water-stressed environments, particularly in the PRD region of Argentina.

Twelve SSRs allowed us to estimate the genetic diversity and structure of PRD plums. These landraces showed a high degree of diversity and a differentiation between accessions with red and yellow flesh.

The genetic fingerprinting profiles could allow the identification and traceability of different genotypes in the various stages of breeding. Furthermore, these profiles could contribute to registering the assessed genotypes in the National Register of Cultivars. The results highlight the utility of bioinformatics to identify genes involved in complex characters to contribute to the understanding of the genetics behind the phenotypic variation. Potentially, the markers close to candidate genes are suitable for comparative QTL mapping, molecular-marker-assisted breeding, and for population genetic studies across different species within the genus Prunus.

Supplementary Materials: The following are available online at http://www.mdpi.com/2073-4395/9/9/487/s1. Table S1 SSR Genotyping Matrix. Table S2 Shared allele distance (DAS) Matrix. Table S3 Mapping and annotation of genes nearby $(<25 \mathrm{~kb}$ window) to polymorphic SSR on the Prunus persica genome.

Author Contributions: Conceptualization, E.H.H., S.N.M.P., T.C. and E.A.F.; methodology, C.V.A., S.M.B.; formal analysis, C.V.A., J.G.R., P.V.V., N.C.A. and M.N.G.; investigation, C.V.A.; resources, T.C. and E.A.F.; writing—original draft preparation, C.V.A.; writing—review and editing, J.V.S.y.G., M.C.M, S.N.M.P. and E.H.H.; project administration, S.N.M.P.; funding acquisition, S.N.M.P.

Funding: This research was funded by the INTA PNBIO-1131044 Project.

Acknowledgments: Special thanks to David Gomez for selecting and collecting the plant material.

Conflicts of Interest: The authors declare no conflicts of interest.

\section{References}

1. Das, B. Prunus diversity—Early and present development: A review. Int. J. Biodivers. Conserv. $2012,3,14$.

2. Mnejja, M.; Garcia-Mas, J.; Howad, W.; Badenes, M.L.; Arús, P. Simple-sequence repeat (SSR) markers of Japanese plum (Prunus salicina Lindl.) are highly polymorphic and transferable to peach and almond. Mol. Ecol. Notes 2004, 4, 163-166. [CrossRef]

3. Kandus, P.; Quintana, R.D. The Paraná River Delta. In The Wetland Book; Elsevier: Amsterdam, The Netherlands, 2016; pp. 1-9. 
4. Caffera, R.; Berbery, H. Climatologia de la Cuenca del Plata. Clim. La Cuenca Del Plata 2006, 20, 19-38.

5. Zagare, V.M.E. Natural territory, urban growth and climate change in the Parana River Delta and Rio de la Plata estuarine system. An Overv. 2016, 1-16.

6. Kandus, P.; Malvárez, A.I. Vegetation patterns and change analysis in the lower delta islands of the Parana River (Argentina). Wetlands 2006, 24, 620-632. [CrossRef]

7. Meis, M.; Llano, M.P. Modelado estadístico del caudal mensual en la baja Cuenca del Plata. Meteorologica 2018, 43, 63-77.

8. Campoy, J.A.; Lerigoleur-Balsemin, E.; Christmann, H.; Beauvieux, R.; Girollet, N.; Quero-García, J.; Dirlewanger, E.; Barreneche, T. Genetic diversity, linkage disequilibrium, population structure and construction of a core collection of Prunus avium L. landraces and bred cultivars. BMC Plant Biol. 2016, 16, 49. [CrossRef]

9. Acuña, C.V.; Fernandez, P.; Villalba, P.V.; García, M.N.; Hopp, H.E.; Marcucci Poltri, S.N. Discovery, validation, and in silico functional characterization of EST-SSR markers in Eucalyptus globulus. Tree Genet. Genom. 2012, 8, 289-301. [CrossRef]

10. Wünsch, A.; Carrera, M.; Hormaza, J.I. Molecular Characterization of Local Spanish Peach [Prunus persica (L.) Batsch] Germplasm. Genet. Resour. Crop Evol. 2006, 53, 925. [CrossRef]

11. Arif, I.A.; Khan, H.A.; Bahkali, A.H.; Al Homaidan, A.A.; Al Farhan, A.H.; Al Sadoon, M.; Shobrak, M. DNA marker technology for wildlife conservation. Saudi J. Biol. Sci. 2011, 18, 219-225. [CrossRef]

12. Verde, I.; Abbott, A.G.; Scalabrin, S.; Jung, S.; Shu, S.; Marroni, F.; Zhebentyayeva, T.; Dettori, M.T.; Grimwood, J.; Cattonaro, F.; et al. The high-quality draft genome of peach (Prunus persica) identifies unique patterns of genetic diversity, domestication and genome evolution. Nat. Genet. 2013, 45, 487-494. [CrossRef] [PubMed]

13. Aranzana, M.J.; Decroocq, V.; Dirlewanger, E.; Eduardo, I.; Gao, Z.S.; Gasic, K.; Iezzoni, A.; Jung, S.; Peace, C.; Prieto, H.; et al. Prunus genetics and applications after de novo genome sequencing: Achievements and prospects. Hortic. Res. 2019, 6, 58. [CrossRef]

14. Carrasco, B.; Díaz, C.; Moya, M.; Gebauer, M.; García-González, R. Genetic characterization of Japanese plum cultivars (Prunus salicina) using SSR and ISSR molecular markers. Cienc. E Investig. Agrar. 2012, 39, 533-543. [CrossRef]

15. Klabunde, G.H.F.; Dalbó, M.A.; Nodari, R.O. DNA fingerprinting of Japanese plum (Prunus salicina) cultivars based on microsatellite markers. Crop. Breed. Appl. Biotechnol. 2014, 14, 139-145. [CrossRef]

16. Vieira, E.A.; Onofre Nodari, R.; Cibele De Mesquita Dantas, A.; Henri, J.-P.; Ducroquet, J.; Dalbó, M.; Borges, C.V. Genetic Mapping of Japanese Plum. Crop Breeding and Applied Biotechnology: Vicosa, Brazil, $2005 ;$ p. 5.

17. Gonz\#xE1;lez, M.; Salazar, E.; Castillo, J.; Morales, P.; Mura-Jornet, I.; Maldonado, J.; Silva, H.; Carrasco, B. Genetic structure based on EST-SSR: a putative tool for fruit color selection in Japanese plum (Prunus salicina L.) breeding programs. Mol. Breed. 2016, 36.

18. Peakall, R.; Smouse, P.E. Genalex 6: Genetic analysis in Excel. Population genetic software for teaching and research. Mol. Ecol. Notes 2006, 6, 288-295. [CrossRef]

19. Botstein, D.; White, R.L.; Skolnick, M.; Davis, R.W. Construction of a genetic linkage map in man using restriction fragment length polymorphisms. Am. J. Hum. Genet. 1980, 32, 314.

20. Chakraborty, R.; Jin, L. A unified approach to study hypervariable polymorphisms: Statistical considerations of determining relatedness and population distances. In DNA Fingerprinting: State of the Science; Birkhäuser Basel: Basel, Switzerland, 1993; pp. 153-175.

21. Langela, O. Populations: A free Population Genetic Software; UCLA: Los Angeles, CA, USA, 2002.

22. Pritchard, J.K.; Stephens, M.; Donnelly, P. Inference of Population Structure Using Multilocus Genotype Data. Genetics 2000, 155, 945-959.

23. Earl, D.A.; vonHoldt, B.M. STRUCTURE HARVESTER: A website and program for visualizing STRUCTURE output and implementing the Evanno method. Conserv. Genet. Resour. 2012, 4, 359-361. [CrossRef]

24. Evanno, G.; Regnaut, S.; Goudet, J. Detecting the number of clusters of individuals using the software structure: A simulation study. Mol. Ecol. 2005, 14, 2611-2620. [CrossRef]

25. Jombart, T.; Devillard, S.; Balloux, F. Discriminant analysis of principal components: A new method for the analysis of genetically structured populations. BMC Genet. 2010, 11, 94. [CrossRef] 
26. Liu, N.; Zhao, H. A non-parametric approach to population structure inference using multilocus genotypes. Hum. Genom. 2006, 2, 353. [CrossRef]

27. Jombart, T. Adegenet: A R package for the multivariate analysis of genetic markers. Bioinformatics 2008, 24, 1403-1405. [CrossRef]

28. Jombart, T.; Ahmed, I. Adegenet 1.3-1: New tools for the analysis of genome-wide SNP data. Bioinformatics 2011, 27, 3070-3071. [CrossRef]

29. Arús, P.; Verde, I.; Sosinski, B.; Zhebentyayeva, T.; Abbott, A.G. The peach genome. Tree Genet. Genomes 2012, 8, 531-547. [CrossRef]

30. Langmead, B.; Salzberg, S.L. Fast gapped-read alignment with Bowtie 2. Nat. Methods 2012, 9, 357. [CrossRef]

31. Olmstead, J.W.; Sebolt, A.M.; Cabrera, A.; Sooriyapathirana, S.S.; Hammar, S.; Iriarte, G.; Wang, D.; Chen, C.Y.; Van Der Knaap, E.; Iezzoni, A.F. Construction of an intra-specific sweet cherry (Prunus avium L.) genetic linkage map and synteny analysis with the Prunus reference map. Tree Genet. Genomes 2008, 4, 897-910. [CrossRef]

32. Yan, A.; Chen, Z. The pivotal role of abscisic acid signaling during transition from seed maturation to germination. Plant Cell Rep. 2017, 36, 689-703. [CrossRef]

33. Li-hui, Z.; Zhi-xiao, H.; Hai-yong, L.; YANG Min-sheng, A. Analysis of Genetic Diversity of Prunus salicina from Different Producing Areas by SSR Markers. Acta Hortic. Sin. 2015, 42, 11-118.

34. Rojas, G.; Méndez, M.A.; Muñoz, C.; Lemus, G.; Hinrichsen, P. Identification of a minimal microsatellite marker panel for the fingerprinting of peach and nectarine cultivars. Electron. J. Biotechnol. 2008, 11, 4-5. [CrossRef]

35. Tani, E.; Polidoros, A.N.; Tsaftaris, A.S. Characterization and expression analysis of FRUITFULL- and SHATTERPROOF-like genes from peach (Prunus persica) and their role in split-pit formation. Tree Physiol. 2007, 27, 649-659. [CrossRef]

36. Schueler, S.; Tusch, A.; Schuster, M.; Ziegenhagen, B. Characterization of microsatellites in wild and sweet cherry Prunus avium-Markers for individual identification and reproductive processes. Genome 2003, 46, 95-102. [CrossRef]

37. Mnejja, M.; Garcia-Mas, J.; Audergon, J.M.; Arús, P. Prunus microsatellite marker transferability across rosaceous crops. Tree Genet. Genomes 2010, 6, 689-700. [CrossRef]

38. González-Agüero, M.; Troncoso, S.; Gudenschwager, O.; Campos-Vargas, R.; Moya-León, M.A.; Defilippi, B.G. Differential expression levels of aroma-related genes during ripening of apricot (Prunus armeniaca L.). Plant Physiol. Biochem. 2009, 47, 435-440.

39. Zhang, B.; Shen, J.; Wei, W.; Xi, W.; Xu, C.-J.; Ferguson, I.; Chen, K. Expression of Genes Associated with Aroma Formation Derived from the Fatty Acid Pathway during Peach Fruit Ripening. J. Agric. Food Chem. 2010, 58, 6157-6165. [CrossRef]

40. Xu, Z.; Sun, L.; Zhou, Y.; Yang, W.; Cheng, T.; Wang, J.; Zhang, Q. Identification and expression analysis of the SQUAMOSA promoter-binding protein (SBP)-box gene family in Prunus mume. Mol. Genet. Genom. 2015, 290, 1701-1715. [CrossRef]

41. Tani, E.; Polidoros, A.N.; Flemetakis, E.; Stedel, C.; Kalloniati, C.; Demetriou, K.; Katinakis, P.; Tsaftaris, A.S. Characterization and expression analysis of AGAMOUS-like, SEEDSTICK-like, and SEPALLATA-like MADS-box genes in peach Prunus persica fruit. Plant Physiol. Biochem. 2009, 47, 690-700. [CrossRef]

42. Roy Choudhury, S.; Roy, S.; Nag, A.; Singh, S.K.; Sengupta, D.N. Characterization of an AGAMOUS-like MADS Box Protein, a Probable Constituent of Flowering and Fruit Ripening Regulatory System in Banana. PLOS ONE 2012, 7, e44361. [CrossRef]

43. Wu, J.; Zhao, G.; Yang, Y.-N.; Le, W.-Q.; Khan, M.A.; Zhang, S.-L.; Gu, C.; Huang, W.-J. Identification of differentially expressed genes related to coloration in red/green mutant pear Pyrus communis. Tree Genet. Genom. 2013, 9, 75-83. [CrossRef]

44. Gou, J.-Y.; Felippes, F.F.; Liu, C.-J.; Weigel, D.; Wang, J.-W. Negative Regulation of Anthocyanin Biosynthesis in Arabidopsis by a miR156-Targeted SPL Transcription Factor. Plant Cell 2011, 23, 1512-1522. [CrossRef]

45. Jaakola, L.; Poole, M.; Jones, M.O.; Kämäräinen-Karppinen, T.; Koskimäki, J.J.; Hohtola, A.; Häggman, H.; Fraser, P.D.; Manning, K.; King, G.J.; et al. A SQUAMOSA MADS box gene involved in the regulation of anthocyanin accumulation in bilberry fruits. Plant Physiol. 2010, 153, 1619-1629. [CrossRef] 
46. González, M.; Salazar, E.; Cabrera, S.; Olea, P.; Carrasco, B. Analysis of anthocyanin biosynthesis genes expression profiles in contrasting cultivars of Japanese plum Prunus salicina during fruit development. Gene Expr. Patterns 2016, 21, 54-62. [CrossRef]

47. Xu, X.; Ma, X.; Lei, H.; Yin, L.; Shi, X.; Song, H. MicroRNAs play an important role in the regulation of strawberry fruit senescence in low temperature. Postharvest Biol. Technol. 2015, 108, 39-47. [CrossRef]

48. Puranik, S.; Sahu, P.P.; Srivastava, P.S.; Prasad, M. NAC proteins: Regulation and role in stress tolerance. Trends Plant Sci. 2012, 17, 369-381. [CrossRef]

49. Lan, T.; Yang, Z.L.; Yang, X.; Liu, Y.J.; Wang, X.R.; Zeng, Q.Y. Extensive functional diversification of the Populus glutathione S-transferase supergene family. Plant Cell Online 2009, 21, 3749. [CrossRef]

50. Zavaliev, R.; Sagi, G.; Gera, A.; Epel, B.L. The constitutive expression of Arabidopsis plasmodesmal-associated class 1 reversibly glycosylated polypeptide impairs plant development and virus spread. J. Exp. Bot. 2010, 61, 131-142. [CrossRef]

51. Janiak, A.; Mirosłw., K.; Iwonas, S. Gene expression regulation in roots under drought. J. Exp. Botany. 2016, 67, 1003-1014. [CrossRef]

52. Xu, B.; Ohtani, M.; Yamaguchi, M.; Toyooka, K.; Wakazaki, M.; Sato, M.; Kubo, M.; Nakano, Y.; Sano, R.; Hiwatashi, Y.; et al. Contribution of NAC Transcription Factors to Plant Adaptation to Land. Science 2014, 343, 1505-1508. [CrossRef]

53. Zhuo, X.; Zheng, T.; Zhang, Z.; Zhang, Y.; Jiang, L.; Ahmad, S.; Sun, L.; Wang, J.; Cheng, T.; Zhang, Q. Genome-Wide Analysis of the NAC Transcription Factor Gene Family Reveals Differential Expression Patterns and Cold-Stress Responses in the Woody Plant Prunus mume. Genes 2018, 9, 494. [CrossRef]

54. Zhou, H.; Lin-Wang, K.; Wang, H.; Gu, C.; Dare, A.P.; Espley, R.V.; He, H.; Allan, A.C.; Han, Y. Molecular genetics of blood-fleshed peach reveals activation of anthocyanin biosynthesis by NAC transcription factors. Plant J. 2015, 82, 105-121. [CrossRef]

55. Fang, Z.-Z.; Zhou, D.-R.; Ye, X.-F.; Jiang, C.-C.; Pan, S.-L. Identification of Candidate Anthocyanin-Related Genes by Transcriptomic Analysis of 'Furongli' Plum Prunus salicina Lindl. during Fruit Ripening Using RNA-Seq. Front. Plant Sci. 2016, 7, 1-15. [CrossRef] [PubMed]

56. Morishita, T.; Kojima, Y.; Maruta, T.; Nishizawa-Yokoi, A.; Yabuta, Y.; Shigeoka, S. Arabidopsis NAC transcription factor, ANAC078, regulates flavonoid biosynthesis under high-light. Plant Cell Physiol. 2009, 50, 2210-2222. [CrossRef] [PubMed]

57. Cheng, Y.; Zhou, Y.-H.; Yang, Y.; Chi, Y.-J.; Zhou, J.; Chen, J.-Y.; Wang, F.; Fan, B.; Shi, K.; Zhou, Y.-H.; et al. Structural and Functional Analysis of VQ Motif-Containing Proteins in Arabidopsis as Interacting Proteins of WRKY Transcription Factors. Plant Physiol. 2012, 159, 810-825. [CrossRef] [PubMed]

58. Custers, J.B.M.; Oldenhof, M.T.; Schrauwen, J.A.M.; Cordewener, J.H.G.; Wullems, G.J.; van Lookeren Campagne, M.M. Analysis of microspore-specific promoters in transgenic tobacco. Plant Mol. Biol. 1997, 35, 689-699. [CrossRef]

59. Cao, K.; Wang, L.; Zhu, G.; Fang, W.; Chen, C.; Luo, J. Genetic diversity, linkage disequilibrium, and association mapping analyses of peach Prunus persica landraces in China. Tree Genet. Genomes 2012, 8, 975-990. [CrossRef]

60. Barnaud, A.; Lacombe, T.; Doligez, A. Linkage disequilibrium in cultivated grapevine, Vitis vinifera. L. Theor. Appl. Genet. 2006, 112, 708-716. [CrossRef] [PubMed]

(C) 2019 by the authors. Licensee MDPI, Basel, Switzerland. This article is an open access article distributed under the terms and conditions of the Creative Commons Attribution (CC BY) license (http://creativecommons.org/licenses/by/4.0/). 